\title{
'N STUDIE GERIG OP DIE BENUTING VAN SIMULASIE AS ONDERRIGSTRATEGIE IN DIE KLINIESE ONDERRIG AFDELING BY ANN LATSKY VERPLEGINGSKOLLEGE
}

\author{
JS Crous, L de Villiers, C Mouton en T Beyers
}

\section{OPSOMMING}

Simulasie verskaf aan die student die geleentheid om kreatlewe gedrag tydens eksperimentering onder gesimuleerde omstandighede te openbaar. In simulasie kan komplekse doelssellings bereik word en potensieell gevaarlik prosedures kan in 'n risiko vrye omgewing ingeoefen word. Simulasie leen hom tot herhaling van 'n aspek wat moeilik deur die student begryp word, asook inoefening van komplekse prosedures tot dat die nodige vaardigheidsvlak en selfvertroue bereik is om dit veilig in die werklike situasie toe te pas. Dit is ook moontlik om leergeteenthede wat nie geredelik beskikbaar is in die praknksituasie in simulasie in te oefen.

Om simulasie effektief te laat realiseer moet die simulasie fasiliteite die praktyksiluasie weerspieêl.

\section{ABSTRACT}

Simulation gives the student the opportunity for creativity while experimenting under simulated circumstances. Simulation provides an area where complex objectives can be achieved and potentially dangerous procedures can be practised in a risk-free area. Students can also repeal aspects of a complicated procedure until they reach the required competency level and gain the necessany self confidence to function in the work situation. Where leaming experiences are lacking in the practical area, simulation could be used.

An effective simulation facility should present the practical situation of the ward.

\section{WETENSKAPLIKE FUNDERING VAN DIE STUDIE}

Inleiding

'n Verslag oor die meningsopname onder vierdejaar studente van 1989 om hulle houding teenoor die basiese opleidingsprogram te bepaal, was gedurende 1990 vrygestel (Vermeulen 1992). Hierdie meningsopname was gerig op vierdejaar studente in die Transvaal wat die Diploma in Verpleegkunde vir registrasie as Verpleegkundige (Algemene-, Psigiatriese- en Gemeenskaps-) en Vroedvrou kragtens R425 van 1985 (soos gewysig) gevolg het.

Die bevindinge van die meningsopname het as motivering gedien om die benutting van simulasie as onderrigstrategie by die Ann Latsky Verplegingskollege na te vors.

\section{Probkemstelling}

'n Meningsopname onder vierdejaar studente wat die basiese diploma in verpleegkunde gevolg het, het getoon dat $88 \%$ van die studente angedui het dat simulasie hulle in staat sou stel om effektief te funksioneer. Daarteenoor het slegs die helfte van die studente aangedui dat simulasie vir hulle van waarde was. Die vraag wat hieruit ontstaan het is: Hoe effektief word simulasie as onderrigstrate gie toegepas tydens kliniese begeleiding by die Ann Latsky Verplegingskollege?

\section{DOEL VAN DIE STUDIE}

Doelstelling

Die doelstelling van die studie is om die effektiwiteit van simulasie as onderrigstrategie tydens kliniese begeleiding by die Ann Latsky Verplegingskollege te bepasl

Doelwitte

Die doelwitte van die studie is om

- die bevoegdheid van die dosent met betrekking tot die gebruik van simulasie as ondenigstrategie te bepasl;
- die mate wasrin die infrastruktuur hom tot simulasie verleen, te bepaal;

- die student se verwagtinge ten opsigte van simulasie as onderrigstrategie tydens kliniese begeleiding te bepaal en

- riglyne daar te stel vir die versekering van effektiewe implementering van simulasie as onderrigstrategie tydens kliniese onderrig

\section{OPERASIONELE TERME}

Simulasie

Simulasie is ' $n$ onderrigstrategie waartydens die leerervaring binne ' $n$ werklikheidsgetroue omgewing wat die werklikheid in 'n gereduseerde en kompakte vorm verteenwoordig, plaasvind.

\section{Onderrigstrategie}

'n Onderrigstrategie verwys na die voordeligste wyse om in metode(-s) van onderrig te gebruik om leer tot gevolg te hê.

Kliniese begeleiding

Kliniese begeleiding is die ondersteuning, aanvulling en beskerming van die afhanklike tot selfstandigwording in die praktiese situasie

\section{Effektiwiteit van simulasie}

Vir die doeleindes van hierdie studie verwys effektiwiteit van simulasie na die mate waarin die toepassing van simulasie as onderngstrategie tot vaardige funksionering van die student in die kliniese praktyk lei.

\section{Dosent}

Vir die doeleindes van hierdie studie is ' $n$ dosent 'n getegistreerde verpleegkundige aan die Ann Latsky Verplegingskollege wat direk betrokke is by kliniese begeleiding van studente (Suid-Afrika 1978 : Artikel 16)

\section{Infrastruktuur}

Die HAT (1982 : 433) definieer infrastruktuur as die "onderste gedeelte van "n struktuur". Vir 
- ber op kognitiewe vlak te bewerketellig. Beekman (1985 : 309) reken dat aimulasie kan bydra tot die ontwikkeling van hotrkognitiewe vaardighede.

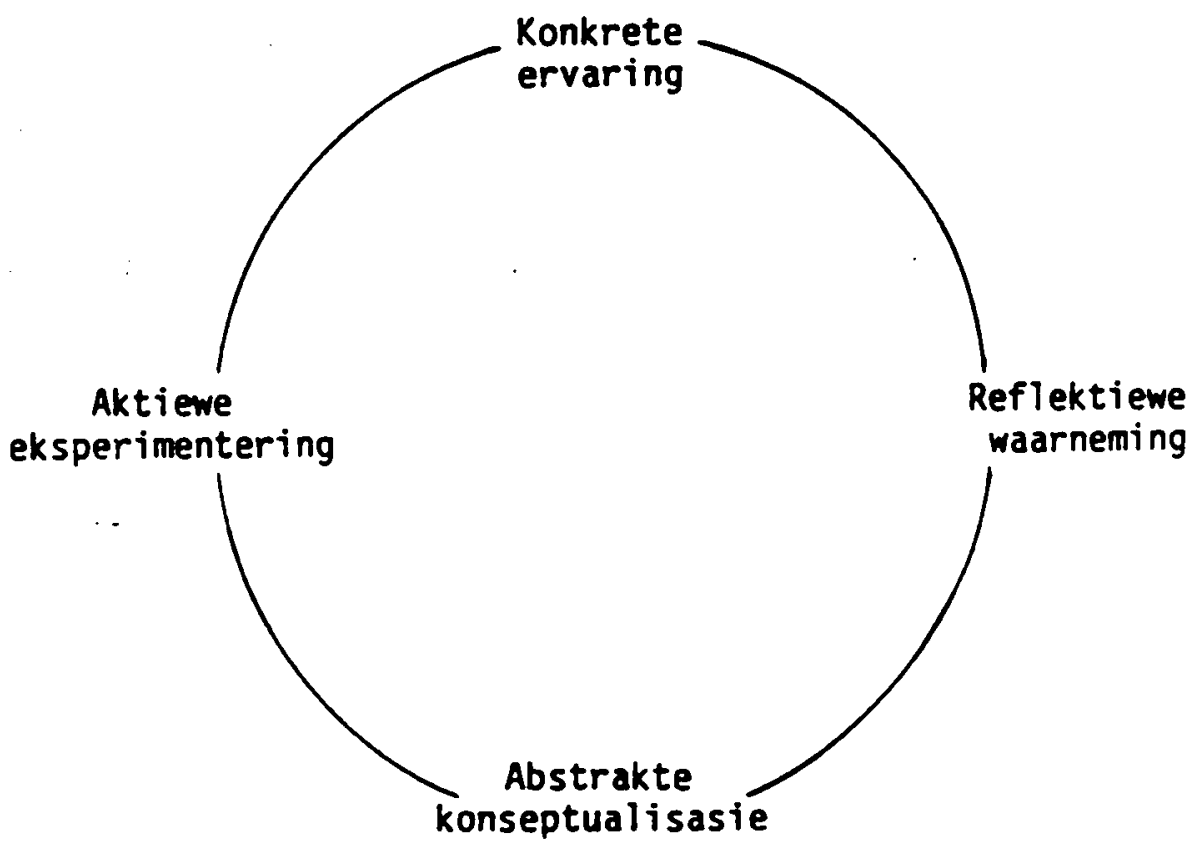

HOLBERT \& THOMAS (1988:3)

die doeleindes van die studie verwys infrastruktuur na die fasiliteite by die kliniese afdelings van hospitale wat geaffilieer is an die Ann Latsky Verplegingskollege, wat beskikbaar is vir die toepassing van simulasie as onderrigstrategie tydens kliniese begeleiding.

\section{Verwagtinge}

Verwagtinge kan beskou word as ' $n$ verstandelike vooruitakatting (persepsie) van hoe dit gaan voel wanneer die persoon haar/hom in 'n spesifieke situasie bevind (Bester 1990: 5)

\section{Student}

Volgens Mellish (1982: 373) is ' $n$ student ' $n$ persoon wat studeer om homself te kwalifiseer vir 'n spesifieke beroep. Volgens hierdie studie is ' $n$ student, ' $n$ persoon verbonde aan die Ann Latsky Verplegingskollege wat tans vir die Diploma vir Registrasic as Verplecgkundige (Algemene-, Psigiatriese-, Gemeenskaps-) en Vroedvrou geregistreer is, kragtens Regulasie No. 425 soos gewysig en wat tans in haar eerste, tweede, derde of vierde studiejas is (SARV 1988).

\section{Riglyne}

Die HAT (1979 : 903) beskryf riglyne as "die lyn wat die rigting aangec; rezls waarvol gens gewerk moet word". Vir die doeleindes van hierdie studie verwys riglyne na die buigsame reEls voortspruitend uit die studie wat die efrektiewe implementering van simulasie as onderrigstrategie tydens kliniese begeleiding rig.

\section{Bevoegdheid}

Bevoegdheid verwys volgens die HAT (1979 : 90) na "die vereiste, bekwaamheid". Bevoegdheid van die dosent is die mate waarin die dosent bekwanm is in die benutting van simulasie as onderrigstrategie soos bepaal deur analisering van haar response op die ingeslote vraelys.

\section{AANNAMES}

Simulasie sal effektief wees indien die dosent die simulasietegniek korrek gebruik

Leer is suksesvol indien die infrastruktuur waarbinne simulasic angewend word asn struktuurstandaarde voldoen.

Simulasie wat volgens prosesstandaarde angewend word sal bydrac tot effektiewe implementering van simulasie en blywende leer.

Simulasie vind effektief plaas indien dit relevant is tot die praktyk.

\section{SIMULASIE AS ONDERRIGBENADERING IN DE KLINIESE PRAKTYK}

Inkiding

Reilly \& Oerman (1985: 113 - 114) beskryf simulasie as " $n$ leerervaring in "n situasie wat die werklikheid naboots of verteenwoordig, maar nie dupliseer nie. Simulasie en -speletjies is onderrigstrategiec om ervaringsleer met die student in 'n aktiewe rol te bewerkstelligsumulasie en -speletjies is van warde om:
- psigomotoriese leer te bewerkstellig. Ewan \& White (1989 : 182) meen dat komplekse paigomotoriese veardighede in beheerde, riaikovrye omstandighede bemeester en ingeoefen word.

- affektiewe leer te bewerkstellig. 'n Strategie 2008 rolspel kan byvoorbeeld angewend word or insig te verkry oor hoe ander dinge warneem. (Beekman 1985 : 89). Empatic word makliker ontwikkel indien die sudent bewus is van die situasie warrin die pasient hom bevind.

- maksimale geleentheid vir begeleide praktyk en terugvoer in 'n werklikheidsgetroue omgewing te verseker.

- verpleegkundige hantering van 'n pasient oor ' $n$ lang tyd perk wit te beeld deur ' $n$ stoekproef van pasient probleme en tussentredes, wat verskeie stadia van die siekteproses veruenwoordig, te selekteer en te onderig. (Reilly \& Oerman 1985 : 113 - 114; Deijon 1978 : 185 : Taney $1971:$ 4)

Beekman (1985 : 85) man egter dat aimulasic nie ' $n$ doel op aigself is nie, maar ' $n$ altematiewe wyse van onderwys.

\section{Kolb se teoric vir ervaringaleer}

Kolb se teorie vir ervaringsleer word as teoretiese ramwerk angeneem. Hierdie teorie beklemtoon die kriticke rol wat ervaring speel in menslike leer en ontwikkeling. Dit biod ' $n$ holistiese ramwerk om menslike loer en ontwikkeling te benader. Ervaringsleer bied hoogs geindividualiseerde leerervarings an leerders en bevorder heelbrein loer. Klem word gepless op:

- hoe om te leer,

- hoe om potensiele leergeleenthede tydens persoonlike ervaring te leer herken en te benut en

- toepassing van kognitiewe leer in praktiese ervaring om versterking, retensie en oordrag van loer te bevorder.

Volgens Kolb (in Holbert \& Thomas 1988 31 ) vind leer in ' $n$ vier fase sikJus pleas. Indien al vier fases voltooi word, word maksimale en blywende leer bevorder

\section{KOLB SE TEORIR}

Die fase van konkrete ervaring word gekenmerk deur aktiwiteit by die student wat inligting genereer. Sodanige ervaring vind in die klaskamer, in die werklikheid of onder gesimuleerde omstandighede plans. (Allan \& Jolly $1987: 85) .0 \mathrm{~m}$ sinvolle ervaring te bewerkstellig word ervaring op voorvereiste kennis gebaseer. Toetsing van voorvereiste 
kennis vind dus voor blootstelling aan die beplande ervaring plaas.

Die fase van reflektiewe waarneming behels die vermoe om bogenoemde ervaring vanuit verskeic perspektiewe te beskou (Holbert \& Thomas 1988 : 31). Allan \& Jolley $(1987: 86)$ beskryf hierdie fase as een wasrin individue wat die ervaring gedeel het, die ervaring met mekaar bespreek om elk se persepsie van die ervaring te verdiep en te verbreed.

Fase drie is die van abstrakte konseptualisasie. Dit word gekenmerk deur die ontwikkeling van konsepte, insig in onderlinge verband tussen die konsepte en die ontwikkeling van teoriex gebaseer op die ervaring in fase een (Holbert \& Thomas $1988: 31$ ). Allan \& Jolley (1987: 87) meen die individu ondersoek die ervaring sistematies, maak sin uit sodanige ervaring en konseptualiseer dit vir latere toepassing in alledaagse werk- of lewenssituasies.

Die laaste fase is die van daadwerklike toepasing van wat geleer is in die allerdaagse situasie, naamlik die van aktiewe eksperimentering (Holbert \& Thomas 1988 : 31).Ervaringsleer, soos alle ander leer, is onderworpe an evaluering. Voorsiening moet dus gemaak word vir vormende en summatiewe evaluering.

Pendleton \& Myles (1991: 145) beskryf die volgende beginsels van ervaringsleer:

- Alle mense leer deur ervaring

- Indien die leer deur al vier fases van ervaringsleer gelei word, word baie geleer en is leer blywend.

Pfeiffer \& Jones (in Pendleton \& Myles 1991

145) beskryf dic effek van dic mate van struktuur waarin ervaringsleer plaasvind Spontane, ongestruktureerde ervaring is noodsaaklik vir persoonlike bewustheid en emosionele ervaring wat as basis vir empatie kan dien. Gestruktureerde ervaring verseker persoonlike groei en standvastige, oordraagbare leer. Die mate van struktuur tydens simulasie, hang dus af van die doel wat nagestreef word.

Ervaringsleer is studentgesentreerd. Dit ontwikkel, benewens taakgeorienteerde bevoegdheid, ook houding en empatic (Pendleton \& Myles 1991: 144 en 146). Simulasie is 'n vorm van ervarmgsleer. 'n Voorvereiste vir effektiewe simulasie is dat al vier fases van ervaringsleer vol tooi moet word tydens die leergebeure. Hierdie studie is gemoeid met simulasie as onderrigstrategie in kliniese onderrig en die navorsers beskou genoemde teorie as ' $n$ geskikte teoretiese raamwerk.

\section{Voordele van simulasie}

Verskeie voordele van simulasie word in die literatuur beskryf. Beekman (1985: 86 - 87) wys daarop dat simulasie ' $n$ direkte ervaring in ' $n$ realistiese, kunsmatige omgewing verskaf. Die student verkry ' $n$ meer gerntegreerde en holistiese siening van dit wat onderrig word.

Beekman (1985: 57 en 90) voer verder aan dat simulasie hom leen tot die toepassing van die didaktiese beginsels van aktiewe leer, ervaringsleer, probleemoplossingsieer, asook realisme en relevansie tydens onderrig.

Aktiewe betrokkenheid verhoog ook motivering by die student

Beekman (1985: 92) is van mening dat standardisering van onderrig en evaluering moontlik gemaak word deur die benutting van simulasie. Die onderwyser kan die student in 'n gestruktureerde omgewing waarneem en vormende evaluering is dus moontlik (NUE 203 - D Studiegids 1990 : 227).

Simulasie verskaf aan die student die geleentheid om kreaticwe gedrag tydens eksperimentering onder gesimuleerde omstandighede te openbaar. Rolspel lewer 'n bydrae tot die interpretering van verskeie rolle en die ontwikkeling van interpersoonlike vardighede. Simulasie speletjies bevorder die ontwikkeling van probleemoplossingsvaardighede en kliniese cordeel (NUE 203 -D Studiegids $1990: 227$ ). Ervaringsleer tydens die benutting van simulasic as onderrigstrategie dra by tot die ontwikkeling van houdings, selfkennis en empatie wat professionele praktykvoering onderlè (Guiné 1966 : 153).Ross (1988:6) reken dat tyd effektief tydens simulasie benut kan word omrede veranderinge wat in die werklikheid oor 'n lang tydperk sou voorkom, onder simulasie met behulp van rekenaarprogramme, rolspel of gevallestudies binne beheerde tydsbestek hanteer kan word. Aspekte in die verloop van ' $n$ chroniese siekte kan byvoorbeeld deur effektiewe steekproefneming in ' $n$ kort tydperk behandel word (Mellish 1982 : 16).

Holzemer (1986 : 231) brei uit deur te sé dat komplekse doelstellings bereik en potensicel gevaarlike prosedures ingeoefen kan word in 'n risikovrye omgewing. Volgens Mellish (1982 : 139) leen simulasie hom ook tot herhaling van 'n aspek wat moeilik deur die student begryp word, asook inoefening van koniplekse prosedures totdat die nodige vardigheidsvlak en selfvertroue bereik is om dit veilig in die werklike situasie toe te pas. Verder is dit ook moontlik om leergeleenthede wat nie geredelik beskikbaar is in die werklikheid nie. te simuleer.

Mellish (1982 : 139) voer an dat teorie en praktyk integrasie bewerkstellig kan word deur besprekings, vraagstelling en verduidelikings tydens simulasie omdat die pasient nie teenwoordig is en dus vrye besprekings inkort nie. Me Guire \& Wezeman (1974 : 19 - 33) beskryf die waarde van simulasie met betrekking tot die moontlikheid on ' $n$ verskeidenheid loerhulpbronne te benut Dit dra by tot teone en praktyk integrasie, asook blywende leer. Uys (1991: 18) het tydens " $n$ navorsingsprojek oor die outotutoriale onderrigmodel as ' $n$ metode van geindividualiseerde onderrig an die Randse Afrikaanse Universiteit, tot die gevolgtrekking gekom dat leergeloenthede logies en geintegreerd angebied en ' $n$ wye verskeidenheid leermateriaal benut word. Herhaling is ook moontlik. Beekman (1985 96) sê dat geindividualiseerde onderrigstrategiec veral van warde is in die teenwoordigheid van " $n$ heterogene studentpopulasie.

Beekman (1990 : 31 - 30) beskryf verdere voordele van simulasie:

- Die gevoelens en waardigheid van die pasient kom nie in gedrang nie;

- Leerdoelwitte geniet voorrang bo diensdoelwitte en

- Die ongewensde invloed van onvoorspelbare, onbeheerde omstandighede op leer kan uitgeskakel word.

Uit bogenoemde blyk dit asof die beginsels van andragogiek met die onderwyser as fasiliteerder van leer, met behulp van simulasie toegepas kan word.

\section{Nadele van simulasie}

Nolte (1986 : 28) reken dat die uniekheid van die pasient as individu, die kompleksiteit van die werklikheid en invloed van onvoorsiene invloede op die werklikheid nie tydens simulasie in ag geneem word nie. Die student kry dus nie ervaring in die hantering van die vermelde faktore nie. Sy voer ook aan dat die student nie die gevolge van haar dade hoef te dra nie en die ontwikkeling van ' $n$ verantwoordbare praktisyn word belemmer Beekman ( 1990 : 32) voer aan dat dit moeilik is om die gedrag wat in die werklikheid openbaar sal word, te voorspel anngesien die werklikheid nageboots en nie gedupliseer word nie. Evaluering in simulasie is dus problematies.

Volgens Pohl (1981 : 107) is simulasie modelle duur en raak maklik beskadig. Dieselfde geld vir dic outotutoriale laboratorium. Die dasrstelling en onderhoud van "n goed toegeruste simulasie laboratorium bring ook geweldige onkoste mee.

Ross (1988 : 7) voer aan dat simulasie in die tenwoordigheid van tydsbeperkinge nie die geskikste strategie is nie omdat dit baic tyd in beslag kan neem, veral as ' $n$ geindividualiseerde benadering gevolg word Om aktiewe betrokkenheid te verseker word studentgetalle tot vyf of ses per sessie beperk. Benewens tyd, word bykomende druk op die onderwysinstansic in terme van mannekragvoorsiening geplass, veral as ' $n$ gebrek an outotutoriale fasiliteite bestaan. Die hantering van groot groepe studente in simulasie om tyd en mannekrag te bespaar, blyk nie gewens te wees nie 
Struktuurstandaarde vir simulasie

Reilly \& Oerman (1985 : 113 - 117) meen dat die omgewing waarbinne simulasie geskied so na as moontlik aan die werklikheid behoort te wees.Lange (1972 : 11 - 13) beskryf die benutting van outotutoriale tegnieke in verpleegonderwys en stel die volgende voorvereiste elemente vir suksesvolle leer voor.

1. 'n Omgewing wat effektiewe ontvangs van stimuli deur die student tydens die leerervaring bevorder.

2. Terugroer aan student rakende doelwitbereiking.

3. Die geleentheid om kliniese vaardighede in te oefen en toe te pas.

Die struktuur waarbinne simulasie plaasvind, behoort voorsiening te maak vir dic elemente.

DIE OMGEWING WAT EFFEKTIEWE ONTVANGS VAN STIMULI DEUR DIE STUDENT BEVORDER

Die leeromgewing behoort hom te leen tot geidividualiseerde leer, groepsessies asook inoefening van kliniese vardighede (kognitief, affektief en psigomotories) totdat die student gereed is om die werklike pasientsorg situasie te betree. Die student behoort geredelike toegang te hê tot 'n begeleier (-s) wat leiding kan gee ten opsigte van kliniese doel witbereiking en die benutting van outotutoriale tegnologie. 'n Gemaklike fisiese omgewing met die minimum steurnisse byvoorbeeld geraas en deurloop, behoort beskikbaar te wees. Daar behoort ook voldoende fasiliteite te wees om die getal studente, met inagneming van die besondere leerstrategie te akkommodeer (Lange 1972 : 13 - 16). Selfgerigte studieareas behoort so ingerig te wees dat voorsiening gemaak word vir multisensoriese stimuli, asook individuele verskille ten opsigte van watter stimuli mees effektief bydra tot suksesvolle leer. Die hipermedia konsep kan hier van waarde wees. Studente behoort dus toegang te hê tot geskrewe literatuur, video's, klankskyfie programma- tuur, rekenaarprogrammatuur, werkboeke om te voltooi, asook spesifieke toerusting om te hanteer tydens leer. Die beskikbaarheid van die studieareas behoort van so ' $n$ aard te wees dat skedulering ten opsigte van die benutting daarvan nie deur die onderriginstansie op studente afgedwing hoef te word nie, aangesien leerdergesentreerdheid nagestreef word. Toerusting, tegnologiese hardeware en sagteware behoort van 'n goeie kwaliteit en in werkende orde te wees. Sagteware behoort ' $n$ spesifieke bydrae tot doelwitbereiking te lewer. In die afwesigheid van geskikte outotutoriale fasiliteite tree ' $n$ ervare en bevoegde kliniese begeleier op as fasiliteerder vir leer. Rolspel en die lesing-demonstrasie is voorbeelde van geskikte onderrigstrategiee in hierdie verband. 'n Volledige toegeruste simulasie laboratorium wat die werklikheid verteenwoordig is steeds ' $n$ vereiste in hierdie geval. Geskeduleerde groepsessies wat gerig is op die bereiking van besondere leerdoelwitte behoort anvullend tot geïndividualiseerde leerfasiliteite beplan te wees. Grootgroepsessies word gereel vir leerervarings wat deur die groep as geheel gevolg moet word. Kleingroepsessies kan as forum dien vir uitbreiding of bespreking van leerervarings, asook vormende evaluering. Die nodige fasiliteite en rangskikking van die fisiese omgewing is noodsaaklik om optimale leer te bevorder (Lange $1972: 13-18+36$ ).

\section{GELEENTHEID VIR DIE INOEFENING} EN TOEPASSING VAN WAT GELEER IS

Inoefening van kliniese vaardighede behels herhaling van die betrokke vaardighede totdat die gewenste vaardigheidsvlak bereik is, asook toepassing darvan tydens die verskaffing van pasientsorg. Beekman (1985

: 144 - 145) wys daarop dat inoefening in die outotutoriale eenheid met toegang tot volledige toegeruste studie - en oefenareas wat 'n hospitaalsaal naboots, kan geskied. In Suid-Afrika word daar dikwels van ' $n$ demonstrasiekamer gebruik gemaak. Die dosent demonstreer dikwels ' $n$ fisiese vardigheid, die student neem waar en oefen daarna die vaardigheid onder begeleiding in. Beekman (1985 : 309) beveel egter aan dat die bestaande en dikwels ontocreikende demonstrasie lokale ontwikkel word tot volwardige simulasielaboratoria met voldoende fasiliteite, toerusting en onderwyspersoneel. Dit behoort ook toeganklik te wees vir die student vir onderrig, inoefening en selfevaluering. Lange (1972:30 - 31) wys op die waarde van die utotutoriale laboratorium vir oefening van kliniese vaardighede. Dit sluit ook die fasiliteite, vir die maak van ' $n$ video-opname van die student se aktiwiteite sodat selfevaluering kan geskied, in. Sy stel voor dat een oefenlokaal beskikbaar behoort te wees vir elke kursus wat aangebied word of vir elke honderd studente, indien daar meer as ' $n$ honderd studente is. Die toepassing van kliniese vaardighede word bevorder deur die beplande plasing van studente in ' $n$ geskikte pasièntsorgsituasie nadat die kliniese begeleier die student se gereedheid tydens ' $n$ voorbereidende leersessie bepaal het. " $n$ Dosent- tot student verhouding van ten minste $1: 15$ word tydens toewysing in die kliniese area vereis om voldoende studentbegeleiding te verseker (Lange $1972: 21$ - 23)

\section{DIE KLINIESE BEGELEIER}

Die kliniese begeleier tree op as fasiliteerder van leer in 'n leergesentreerde omgewing. (Reilly \& Oerman 1995: 114) Beekman (1985 :90) sê die kliniese begeleier is minder betrokke by dissiplinering en oordeel, maar meer empaties en nader aan die student. Indien 'n outotutoriale benadering gevolg word, is die outotutoriale tegnikus behulpsaam met die benutting van outotutoriale hulpmiddels vir doelwitbereiking. Die kliniese begeleier speel ' $n$ rol by die outotutoriale leersessies. praktykbegeleiding en evaluering. Sy hanteer ook probleme met doelwitbereiking (Lange 1972 : 38 - 41). Entoesiasme en kreatiwiteit word beskou as kenmerke van die kliniese begeleier. Reilly \& Oerman (1985 : 113) meld die waarde van 'n stewige kennisbasis waarop die begeleier haar onderrig baseer. Sy behoort ook deeglik voorberei te wees ten opsigte van die recls van 'n gegewe simulasie strategie, asook die spesifieke riglyne wat aan studente gegee behoort te word om effektiewe leer tot gevolg te hê. Sensitiwiteit ten opsigte van die student se individualiteit, gereedheid en eiesoortige probleme is van waarde sodat buigsaamheid tydens leer en individuele begeleiding in geval van probleme, die leersituasie kenmerk (De Villiers 1975 : 47; Dejon 1978 : 75). Kennis van die kurrikulum en stadiumdoelstellings waarvolgens ' $n$ betrokke student leerdoelwitte bereik, verseker relevansie van kliniese doelwitbereiking (Dejon 1978 : 185). In geval van ' $n$ demonstrasie, is die kliniese dosent bedrewe in die hantering van toerusting en voltooiing van die aktiwiteit. Sy lig ook werksaamhede toe met logiese, duidelike kommentaar. De Villiers (1975: 47) beklemtoon die vermoę om vormend te evalueer ooreenkomstig verwagte vaardigheidsvlakke. Benewens bogenoemde is deeglike kennis met betrekking tot struktuur- en prosesstandaarde vir simulasie noodsaaklik.

\section{Prosesstandaarde tydens simulasie}

Lange (1972: 18) identifiseer die volgende beginsels warop studentgesentreerde outotutoriale onderrig berus.

1. Die student bepaal op watter stadium besondere kliniese doelwitte bereik word. Dit verseker dat die student se behoeftes aangespreek, asook teorie en praktyk korrellasie verwesenlik word. 'n Student kan byvoorbeeld ehirurgie-verwante doelwitte bereik wanneer sy in ' $n$ ehirurgiese cenheid werksaam is.

2. Klem word gelê op doelwitbereiking eerder as ' $n$ voorgeskrewe aantal ure vir 'n besondere voorgeskrewe leeraktiwiteit. Dit verseker dat individuele verskille ten opsigte van leertempo in ag geneem word.

3. Die student bepaal watter leerhulpbronne benut gaan word. Voorsiening word dus gemaak vir individuele verskille ten opsigte van inset stimuli wat leer vergemaklik

4. Die kriteria vir evaluering is werkverrigting eerder as aantal ure gewy aan besondere leerdoelwitte. Verskeie fases is betrokke in die leerproses.

\section{DIE VOORBEREIDENDE SESSIE}

Lange ( $1972: 45$ ) reken dat betreding van elke leereenheid voorafgegaan word deur 'n 
voorbereidende sessie waarby die kliniese begeleier en student betrokke is. Die onderwyser bepaal of die student oor voldoende voorvereiste kennis beskik vir sinvolle voltooiing van die leereenheid wat die student beoog om te voltooi. Onvoorbereide studente word weggewys om voorvereiste doelwitte te bereik, terwyl die ander georienteer word ten opsigte van die beplande leereenheid. Die doelwitte van die leereenheid, aspekte wasrop studente behoort te fokus, asook duidelike riglyne vir suksesvolle doelwitbereiking word verskaf. (Reilly \& Oerman 1985 : 117 ; NUE 2.3 - D Studiegids $1990: 230-233$ ).

\section{DIE KLINIESE LEERSESSIE}

\section{Die insetfase}

Tydens die insetfase verkry die student kennis in verband met die kliniese vaardigheid wat aangeleer word, asook die teoretiese grondslag waarop dit berus. Dit kan geskied deur middel van die benutting van die outotutoriale studieareas of die behartiging van ' $n$ onderrig-leersessie deur die kliniese dosent in " $n$ simulasie laboratorium en groepsessies. Die fasiliterende rol van die dosent bly egter steeds belangrik in laasgenoemde geval. (Reilly \& Oerman 1985 : 117). Lange (1972:45) stel voor dat studente in groepies van vyf verdeel behoort te word om die dosent in stat te stel om individuele andag aan elke student te gee. Volgens Reilly \& Oerman (1985: 117) behoort simulasie gerig te wees op die besondere leerdoelwitte en behoort ' $n$ bydrae te lewer tot verbeterde hantering van situasies in die kliniese veld. Relevansie is dus noodsaaklik. Vormende evaluering en konstruktiewe terugvoer word as integrale deel van die leeraktiwiteit beskou. (Beekman 1990 : 32).

\section{Die verrykingsfase}

Die insetfase word opgevolg deur aktiwiteite wat verryking van leer bewerkstellig. Groepbesprekings of dosent-student besprekings kan aangewend word om die leerervaring in perspektief te plaas en konseptualisering te bevorder. Optimale toorie en praktyk korrellasie word ook tydens hierdie fase nagestreef. Onbeantwoorde vrae en probleme word opgeklaar (Lange 1972 : 47).

\section{INOEFENING EN TOEPASSING VAN AANGELEERDE VAARDIGHEDE}

Beekman (1985 : 310) stel voor dat meer geleenthede vir inoefening onder gesimuleerde omstandighede aan die student gebied behoort te word. Volgens Lange (1972

$30-31$ ) is vormende evaluering, veral selfevaluering ' $n$ integrale deel van die inoefeningsfase. Inoefening vind plaas, totdat die vereiste vardigheidsvlak bereik is Leeroordrag word bevorder deur die toewysing van die student aan die toepaslike pasientsorgarea. Die toewysing word beplan om toepassing van die besondere aangeleerde vardighede so spoedig moontlik na doelwitbereiking, te bewerkstellig. Kliniese toewysing word voorafgegaan deur evaluering deur die kliniese begeleier af geneem om te verseker dat die voorvereiste vaardigheidsvlak vir veral pasientsorg deur die student bereik is. Mellish (1982 : 39) beklemtoon die belang van die saalsuster betreffende die opvolging van die student in die praktyk. Die kliniese dosent bly egter steeds ' $n$ belangrike hulpbron tydens hierdie fase.

\section{Navorsingbevindinge}

Nel \& Basson (1988 : 23 - 27) kom na voltooide navorsing met betrekking tot spesifieke leergeleenthede in gesondheidsopvoeding tot die volgende gevolgtrekkings ten opsigte van groepbesprekings en rolspel as onderrigstrategiee in beide die klaskamer as die kliniese situasie:- Groepbesprekings en rolspel gee an studente die geleentheid om aktief aan die leerproses deel te neem;Studente wat blootgestel word aan groepbesprekings en rolspel om leerinhoude in te oefen, kan dit beter onthou en herroep. Hoer kognitiewe vaardighede word ook bekom as by studente wat slegs blootgestel word aan ' $n$ formele lesing om leer inhoude aan hulle oor te dra.

- Die dosent kry geleentheid om elke student se vordering te evalueer en deurlopende begeleiding op grond hiervan te bied;

- Rolspel en groepbesprekings berei studente meer effektief voor om aktiewe gesondheidsvoorligting te gee as die formele lesing;

- Rolspel en groepbespreking lewer 'n wasdevolle bydrae tot die ontwikkeling van interpersoonlike vaardighede en

- Daar behoort reeds vroeg in die opleidingskursus aandag gegee te word aan die vermoe van die student om sensitief te wees vir hul kliènte se gedrag.

Beekman (1985 : 298 - 299) kom in haar navorsing tot die gevolgtrekking dat:

- simulasie beter resultate lewer in die ontwikkeling van probleemoplossing vaardighede as tradisionele onderwys; Tydens ' $n$ eksperimentele studie het studente wat aan simulasie onderwerp was, beter presteer in probleemoplossing, as studente wat tradisionele onderwys ontvang het,

- die dosent die onderrig - leersituasie tydens simulasie kan beheer met betrekking tot die akkommodasie van werklikheidsprobleme in die kliniese situasie;

- die gaping tussen teorie en praktyk vernou tydens die benutting van simulasie en

- simulasie as onderrigstrategie voldoen aan didakties opvoedkundige vereistes soos deelname, selfwerksaamheid, ervaring en probleemoplossing. Sel fstandigheid en hoer kognitiewe denke word ook bevorder. Die dosent behoort didakties goed onderlê en toegerus te wees vir didakties verantwoordbare hantering van die onderrigleersituasie.

Beekman (1985 : 301 - 304) spreek egter has kommer uit oor die algemene onvermot van die student ten opsigte van probleemoplossende denke en optrede. Sy identifiseer onderandere die volgende moontlike oorsake.

- Onderrig word dikwels, toegespits op memorisering en hantering van feite;

- Onderrig is dosentgesentreerd met die student in 'n grootliks passiewe rol en

- Die student word nie toegelaat om self te dink en doen nie. Selfevaluering word ook verwaarloos.

Die voordele van simulasie lé in individualisering, deelname en probleemgerigtheid.

Die posisie van simulasie by die Ann Latsky Verplegingskolkge

Die filosofie en beleid van die kollege beklemtoon die benutting van die beginsels van die andragogiek. Die andragogiek is die loerdergesentroerde wetenskap en kuns om volwassenes op 80 'n wyse te help leer, dat selfgerigte leer en funksionering as doel verwenslik word (Quinn 1988 : 46 ; Nielsen $1989: 86)$. Verskeic aspekte van die andragogiek word uitgelig.

- Die leerder is verantwoordelik en anspreeklik ten opsigte van leer. (Allan \& Lolley 1987 : 103). 'n Leerkontrak kan benut word (Gartside \& Mc Gough 1991 : $40-41$ ).

- Die onderwyser tree op as fasiliteerder van leer (Nielsen 1989: 87).

- 'n Bevoegdheidsgebaseerde benadering word gevolg (Quinn 1988: 46). Bemeesteringsleer word dus voorgestaan.

- Die onderrigleetprogram is buigsaam om in individuele behoeftes en verskille te voorsien (Quinn 1988 : 46). Die loerder word gelei na toenemende selfgerigtheid met inagneming van haar volwassenheidsvlak.

- Vormende evaluering wat selfevaluering insluit, vorm integrale deel van die leerproses (Gartside \& McGough 1991 : 40 -41).

- Ervaringsleer word benut om loer deur middel van persoonlike ervaring te bevorder, asook die student aktief te betrek (Allan \& Jolley 1987 : 103). Daarbenewens kan die volwassene se ryke ervaringskatkis benut word om verdere loer op te baseer. 
(Nielsen 1989 : 88). Volgens Knowles (1980: 202) bevorder bogenoemde leeroordrag effektiewe werkverrigting. Pendleton \& Myles (1991 : 146) stel voor dat verskeie onderrigstrategiee angewend behoort te word om leer te bevorder.

- Relevansie van leerervarings in terme van toepassingswaarde is noodsaaklik by volwasse leer. 'n Praktykverwante cerder as vakgesentreerde benadering word dus gevolg wat die onmiddellike toepassing van leer in die praktyk insluit (Nielsen $1989: 87$ ).

Simulasie is versoenbaar met die beginsels van andragogiek. In die lig van bogenoemde word simulasie as onderrigstrategie as van belang beskou by die kollege. Die gelndividualiseerde aard die benutting van die andragogiese beginsels vergemaklik onderrig aan ' $n$ heterogene studente groep. Die geregistreerde studente van dié Kollege verskil ten opsigte van ouderdom, ontwikkelingsvlak, persoonlike omstandighede en kultuur. Studente wissel byvoorbeeld van skoolverlaters tot middeljariges met onafhanklike kinders. Sommige studente betree die basiese verpleegkursus nadat hulle reeds ' $n$ ander graad- of diploma kursus voltooi het. ' $n$ Geindividualiseerde onderrigbenadering is dus noodsaaklik om in alle studente se behoeftes te voorsien.

\section{NAVORSINGSMETODOLOGIE}

\section{Navorsingsontwerp}

Die navorsingsontwerp is ' $n$ verkennende, beskrywende ontwerp binne konteks van die Ann Latsky Verplegingskollege en geaffilicerde hospitale.

\section{Navorsingsmetode}

'n Beskrywende opname metode met gebruikmaking van 'n gestruktureerde vraelys word gebruik. Vier vraelyste is uitgestuur. Vraelyste gerig op struktuurstandaarde en prosesstandaarde is aan studente en dosente onderskeidelik gestuur. Die vraelys gerig op prosesstandaard weerspieel Kolb se vier fases van ervaringsleer.

\section{Data insameling}

'n Gestruktureerde vraelys bestaande uit geslote sowel as oopeinde items is ingesluit. Hierdie metode leen hom tot die anonieme verkryging van die respondente se opinies rakende die toepassing van simulasie in die kliniese areas van toepassing. Die oopeind vrae leen hom tot vrye response wat insig in die studieveld bevorder terwyl die geslote vrae data-analise vergemaklik (Polit \& Humgler $1987: 229-231$ ).

\section{Steekproefneming}

Dosente $(100 \%)$ populasic bestaande uit dosente betrokke by Algemene
Verpleegkunde en Verloskundige Verpleegkunde. Daar is 32 vraelyste aan dosente uitgegee en terug ontvang. Al die dosente wat betrokke is by Algemene en -Verloskundige verpleging het vraelyste ontvang.

Studente Proporsionele ewekansige stratifiseerde streekproef- neming is gedoen as volg:

Die student populasie is in strata volgens hospitale waar kliniese onderrig plaasvind, verdeel byvoorbeeld eerste-, tweede-, derdeen vierdejaars. ' $n$ Tien persent ewekansige streekproef is uit elke stratum getrek. Die steekproefnemings- tegniek het verseker dat 'n nie-tipiese steekproef voorkom word. Binne elke stratum is ewe kansigheid steeds verseker aangesien respondente lukraak gekies is. Veralgemenings na die populasie was dus moontlik. Vyftig vraelyste is aan die studente uitgegeeen 32 vraelyste is terug ontvang. Dic aantal respondente wat die vraelys beantwoord het was dus:(32) studente en (32) dosente.

\section{Data analise}

Beskrywende statistieke byvoorbeeld frekwensie-tabelle, rekenkundige gemiddeld, item-analise is gebruik om die resultate van die navorsing weer te gee.Rekenkundige gemiddelde is bereken.

\section{Geldigheid en betroubaarheid}

Geldigheid van die studie word verseker deur die navorsingsprotokol en instrument aan kundiges te besorg vir kommentaar en aanbevelings. Die items in die vraelys is spesifiek gefokus op die besondere navorsingsdoelwit wat bereik wil word. Om betroubaarheid te verseker is:

- hoofkonsepte gedefinieer en geoperasionaliseer,

- items in vraelys kort, duidelik en ondubbelsinnig geformuleer,

- 'n toepaslike steekproefnemingstegniek aangewend om ewekansigheid te verseker,

- toepaslike statistiese metodes vir data verwerking aangewend en

- die instrument is onderwerp aan ' $n$ loodsstudie (Polit \& Hungler $1987: 313$ 329; Treece \& Treece $1986: 271$ ).

Beperkinge van die studie

Beperkinge van die studie was as volg

- Die dosente het hulself weerspreek in die proses en struktuur vraelys en dit kan die betroubaarheid van die inligting verkry uit die vraelys beinvloed.

- Die populasie was beperk in omvang, aangesien die studie slegs gerig is op die
Ann Latsky Verplegingskollege. Veralgemenings van die resultate is dus beperk tot die Ann Latsky Verplegingskollege.

- Kontaminasie is moontlik omrede respondente mekaar kon beinvloed het met betrekking tot simulasie.

- Die oop einde vrae het data verwerking bemoeilik.

\section{Etiese corwegings}

Om binne etiese parameters op te tree het die navorsers:

- toestemming van die betrokke instansie verkry;

- anonimiteit van respondente verseker;

- die reg tot vrywillige deelname van respondente beskerm;

- respondente voldoende ingelig oor dic aard en rede van die navorsingsprojek;

- geen respondent beinvloed om ' $n$ besondere respons te lewer nie;

- data-ontleding cerlik en objektief benader;

- interpretasies en gevolgtrekkings gebaseer op navorsingsresultate en nie die begeerte om ' $n$ eie mening te steun nie en

- erkenning gege aan geraadpleegde bronne en mede-navorsers se bydraes.

\section{DATA-ANALISE}

\section{Inkiding}

Ontleding van die navorsingsresultate is gedoen volgens itemanalise, rekenkundige gemiddeld en frekwensie tabelle.

Die faktore wat in hierdie studie onleed word is:

\section{A. PROSES: (Student en dosent vraclys)}

1. Biografiese inligting

2. Voorbereiding en voorvereiste kennis

3. Konkrete ervaring

4. Reflektiewe wasmeming

5. Abstrakte konseptualisering

6. Eksperimentering

7. Evaluering

B. STRUKTUUR (Student en dosent vraelys)

1. Biografiese inligting

2. Konkrete ervaring 


\section{Reflektiewe waameming}

\section{Aktiewe eksperimentering}

\section{Bespreking van resultate}

Die resultate van die navorsing word bespreek volgens die student se vraelys (proses en struktuur), en daarna die dosent se bevindinge onder dieselfde genoemde hoofde.

\section{A. PROSES}

Student

\section{Student biografiese inligting}

Die biografiese inligting het bestaan uit:

- hospitale waar kliniese praktika gedoen word;

- ouderdomsgroep van die student;

- kursus / studierigting waarvoor die student voorheen geregistreer was;

- studiejaar / jaargroep waarvoor die student geregistreer is en

- studiejaar wat die student herhaal

\section{Voorbereiding en voorvereiste kennis}

Die data toon dat vier (13\%) van die studentverploegkundiges minder as "n uur aan voorbereiding vir gerigte praktykleiding spandeer het. Sestien $(50 \%)$ van die studentverpleegkundiges spander tussen $l$ tot 2 ure aan voorbereiding. Elf ( $34 \%$ ) spandeer 3 tot 4 ure aan voorbereiding vir gerigte praktykleiding. Slegs vier (13\%) het meer as vyf ure spandeer aan voorbereiding. Die redes waarom die studente meer as vyf ure spandeer het an voorbereiding was, dat die voorvereiste doelwitte wat op die kriteriumverwysingskaarte verskyn, uitgewerk moet word, en van die doelwitte vereis meer naslaanwerk as ander. Die studente het dus redelik tyd bestee aan voorbereiding vir gerigte praktykleiding.

Toets van bestaande kennis voor gerigte praktykleiding sessies Meer as een metode van voorvereiste kennisevaluering het plaasgevind en word as volg voorgestel.

\section{Tabel 4.1 Metode van voorvereiste kennisevaluering ( $\mathbf{N}=\mathbf{3 2}$ )}

\begin{tabular}{lcr} 
EVALUEAING & Persentasie & $\begin{array}{r}\text { Aantal } \\
\text { studente }\end{array}$ \\
$\begin{array}{l}\text { Geskrewe toets } \\
\begin{array}{l}\text { Vraaggetelling deur } \\
\text { dosent }\end{array}\end{array}$ & 34 & 11 \\
$\begin{array}{l}\text { Kontrolering ven } \\
\text { uttoewerkte doolwitte }\end{array}$ & 28 & 18 \\
$\begin{array}{l}\text { Terug-demonstreor } \\
\text { van vaardighede deur } \\
\text { middel van rolspel } \\
\text { of eaalrondtes }\end{array}$ & 25 & 0 \\
\hline
\end{tabular}

Met die oopeinde vraag oor die kennisevaluering het een (3\%) student gemeld dat voorvereiste kennis nie getoets word nie en dat die dosent net voor " $n$ eksamen aandag aan die studente $g \propto c$. Die metode wat die dosent die meeste gebruik het om voorvereiste kennis te toets is vraagstelling.

\section{Konkrete ervaring en reflektiewe wasmeming}

- Vier en twintig (75\%) van die studente beskou simulasie as die aanleer van vaardighode in "n kunsmatige situasie waar die werklikheid nageboots word

- Die onderrigstrategiec waaraan die studente tydens gerigte praktykleiding blootgestel was behels:

- Die vaardighede wat die studente in simulasic aageleer het, behels:

\begin{tabular}{|c|c|c|}
\hline \multicolumn{3}{|c|}{ Tabel 4.2 Onderrigstrategleó } \\
\hline Onderrigatrategiè & Persentasio & $\begin{array}{l}\text { Aantal } \\
\text { studente }\end{array}$ \\
\hline Gevallestudie & 66 & 21 \\
\hline Simulasie & 56 & 18 \\
\hline Demonstrasie & 50 & 16 \\
\hline Rolspel & 34 & 11 \\
\hline $\begin{array}{l}\text { Kombinasie van } \\
\text { onderrigstrategiea } \\
\text { word gebruik }\end{array}$ & 49 & 15 \\
\hline Blokkiesraaisel & 62 & 20 \\
\hline Sealrondtes & 62 & 20 \\
\hline $\begin{array}{l}\text { Praktiese } \\
\text { vaardighede } \\
\text { (bedwas) }\end{array}$ & 24 & 30 \\
\hline $\begin{array}{l}\text { Onderhoud } \\
\text { voering }\end{array}$ & $\infty$ & 22 \\
\hline $\begin{array}{l}\text { Beraming } \\
\text { van 'n pasient }\end{array}$ & 34 & 11 \\
\hline $\begin{array}{l}\text { Fisieke } \\
\text { ondersoek }\end{array}$ & 69 & 22 \\
\hline $\begin{array}{l}\text { Interpersoonlike } \\
\text { vaardighede }\end{array}$ & 59 & 18 \\
\hline Rolspel & 81 & 26 \\
\hline
\end{tabular}

Die gevolgtrekking kan dus gemaak word dat die studente meestal praktiese vardighede in simulasic aanleer terwyl blokkiesraaisels en saalrondtes nic dikwels deur dosente gebruik word nie. Daar word ook heelwat aandag gegee aan interpersoonlike vardighode soos onderhoudvoering.

- Agt-en-twintig (88\%) studente het ervaar dat die dosent voorbereid is terwyl (9\%) ervaar dat die dosent soms voorbereid is. Slegs een (3\%) student het gevoel dat die dosent onvoorbereid is wanneer onderrigstrategiex geimplenenteer word

- Nege en twintig (91\%) beweer dat hulle betrek word by simulasieaktiwiteite wat mel groepbesprekings opgevolg word

- Al die studente word a an nadenke blootgestel deur middel van vraagstelling tydens simulasie, terwyl 'n gemoodelike atmosfeer heers.

- Twee-en-dertig $(100 \%)$ van die studente het die vrymoedigheid om vir die dosente te vra, indien hulle nie verstaan nie. Een student het gemeld dat die dosent nie altyd 'n antwoord kan gee nie.

\section{Refkektiewe waarneming}

Bevindings sal bespreek word in volgorde van vrae wat gestel is.

- Leer wat in simulasic plaasgevind het, word met ' $n$ groepbespreking opgevolg.

- Nege-en-twintig $(91 \%)$ van die studente beweer dat leer wat in simulasie plaasgevind het opgevolg word met ' $n$ groepbespreking.

Die studente het die volgende opmerkings neergeskryf oor hul beskouing van groepbespreking:

- Dit bied ' $n$ geleentheid om vrae te stel;

- Sommige studente het iets waargeneem tydens ' $n$ demonstrasie wat ander nie raakgesien het nie

- Studente lewer interessante bydraes met betrekking tot dit wat hulle opgelees het,

- Foute word uitgewys en die korrekte metode word bespreek;

- Almal leer saam;

- Meer sinvol en

- Versterk weer wat belangrik is.

- Moedig die dosent nadenke aan deur middel van bespreking of vraagstelling

Nadenke word deur middel van bespreking of vraagstelling angemoedig (agt-en-twintig (88\%) van die studente het dit ondervind) dat om sinvolle ervaring te bewerkstellig word ervaring op voorvereiste kennis gebaseer veruys na paragraaf 1.2)

Het u die vrymoedigheid om die dosent te vra, om aspekte wat u nie verstan nie, weer te verduidelik en of $u$ meer inligting wil bekom oor 'n onderwerp.

Dertig $(94 \%)$ van die studente het die vrymoedigheid om die dosent te vra om aspekte wat hulle nie verstaan nie, weer te verduidelik.

\section{Abstrakte konseptualisering}

Word $u$ aangemoodig om die kennis wat u verwerf het as konsepte te formuleer

Een-en-dertig (97\%) van die studente word anngemoedig om hulle kennis volgens konsepte te formuleer en toe te pas. Volgens Allan \& Jolley (1987: 87) ondersock die 
individu ervaring sistematies, maak sin uit ervaring en konseptualiseer dit vir latere toepassing in alledaagse werk- of lewenssituasies.

\section{Eksperimentering}

Die inligting toon dat een-en-dertig (97\%) van die studentverpleegkundiges ervaar dat simulasic as onderrigstrategiec, effektiewe werkverrigting in die werklike situasie bevorder. Volgens die navorsers is simulasie ' $n$ vorm van ervaringsleer. " $n$ Voorvereiste vir effekticwe simulasie is dat al vier fases ervaringsleer voltooi moet word tydens die leergebeure rwys na bladsy 4). Simulasie gee an die student geleentheid om kreatiewe gedrag onder gesimuleerde omstandighede te openbaar (verwys na paragraaf 2.4 )

Die interpretasie wat gemaak word dat die toepassing van simulasie as onderrigstratgic en die gepaardgaande blootstelling wat dit die student bied, die student instaat stel om met selfvertroue die kliniese praktyk te betree.

\section{B. PROSES}

\section{Dosent}

\section{Biografiese inligting}

Die biografiese inligting het bestaan uit:

- Kliniese begeleiding by verskillende hospitale;

\section{- Ouderdomsgroepe van dosente en}

- Verwerwing van onderwyskwalifikasie.

Agt-en-dertig (12\%) van die dosente kom tussen die ouderdomsgroep 25 - 34 jaar voor. Agt (25\%) van die dosente kom in die ouderdomsgroep 35 - 39 voor. Dertien persent $(4 \%)$ van die dosente kom in die ouderdomsgroep 50 en ouer voor. Die gevolgtrekking word gemaak dat die Ann Latsky Verplegingskollege uit ' $n$ jong korps dosente bestaan.

Die aantal jare sedert die verwerwing van die onderwyskwalifikasic is:

- Tien dosente het die onderwyskwalifikasie 1 tot 4 jaar gelede verwerf;

- Vyf tot agt jaar gelede het twaalf dosente die onderwyskwalifikasie verwerf en

- Tien dosente het die kwalifikasie meer as twaalf jaar gelede verwerf

Sedert die dosente hulle onderwys$k$ walifikasie verwerf het is ' $n$ aanduiding van hulle ondervinding in verpleegonderwys.

\section{Voorbereiding en voorkennis}

Die dosente spandeer oorwegend 1 - 2 ure aan voorbereiding vir gerigte praktykleiding. Sewentien $(53 \%)$ van die dosente toets voorvereiste kennis. Een van die dosente wat gemeld het dat voorvereiste kennis van studente nie getoets word nie, het gemeld dat die studente mekaar se voorkennis kontroleer en daarna word dit bespreek. Dertien (41\%) van die dosente maak gebruik van vraagstelling. Kontrolering van uitgewerkte voorvereiste doelwitte word deur tien (31\%) van die dosente uitgevoer. Die maatreels wat die dosente tref indien " $n$ student nie aan dic voorvereiste doelwitte voldoen nie, was:

- Twee-en-dertig (100\%) van die dosente formuleer spesifieke doelwitte wat die studente moet bereik;

- Agtien ( $56 \%$ ) van die dosente weier om die student se vormende evaluering uit te voer,

- Agtien (56\%) van die dosente gee moer tyd aan die student om doelwitte te bereik;

- Twee-en-dertig (100\%) van die dosente skryf ' $n$ opmerking in die student se leerkontrak dat die student die doelwitte nog moet bereik;

- Drie $(9 \%)$ van die dosente hersien weer die inhoud wat tydens die blokprogram onderrig is:

- Agtien (32\%) van die dosente stel ' $n$ sperdatum wanneer doel witte bereik moet word en

- Agtien (32\%) van die dosente formuleer nuwe doelwitte en voer ' $n$ onderhoud met die student.

Die dosente is voorbereid vir gerigte praktykleiding. Dit is egter kommerwekkend dat slegs die helfte van die dosente dit nodig ag om studente se voorkennis te toets aangesien dit ' $n$ groot deel van haar kognitiewe kennis verteenwoordig. Wat ook kommerwekkend is is dat slegs $3 \%$ studente getoon het dat voorvereiste kennis nie getoets word nie. Diskrepans kom dus voor. Wat hier ook ' $n$ probleem is, is dat $53 \%$ dosente voorvereiste kennis toets mar $100 \%$ byvoorbeeld ' $n$ opmerking in die leerkontrak skryf. Die gevolgtrekking kan gemaak word dat die respondente die vrae nié eerlik beantwoord het nié, omdat ' $n$ inskrywing op die leerkontrak beteken dat voorkennis getoets word.

\section{Konkrete ervaring en renektiewe waarneming}

Sestien (50\%) dosente gebruik simulasie wanneer die geleentheid roorkom. Twee-en-dertig (100\%) van die dosente beskou simulasie as ' $n$ waardevolle onderrigstrategie terwyl sestien ( $50 \%$ ) hulself as vardig beskou om simulesie te gebruik Dus sal in personeelontwikkelingsprogram ingestel moet word om die dosente wat hulself nie vaardig beskou het in die gebruik van simulasie as onderrigstrategie nie. Al die dosente betrokke by die navorsingsprojek maak van die onderstaande metodes gebruik om die studente tydens simulasic aktief te betrek is:

- die student voer self die prosedure uit;

- deur vraagstelling;

- deur bespreking gedurende en aan die einde van ' $n$ demonstrasie en

- mondelingse terugvoer deur die student.

\section{Abstrakte konseptualisering}

Ses (19\%) van die dosente maak gebruik van konsepformulering gedurende simulasic. Dit kan die toorie en praktyk integrasie belemmer omdat konsepte wat in teorie onderrig word nie deur die dosente in die praktyk met voorbeelde aan die studente meld nie. Diskrepans tussen dosente en studente se response kom voor, aangesien $97 \%$ studente reken konsepformulering vind wel plaas.

\section{Eksperimentering en evaluering}

Volgens die respondente vind onafhanklike inoefening in die derde- en vierdejaar plaas. Die derde- en vierdejaar studente het alreeds 3 tot 4 jaar praktyk ervaring opgedoen en benodig dus nic meer inoefening of demonstrasies in simulasie nie. Die studente is ook aan ' $n$ selfgerigte begeleidingstelsel blootgestel en funksioneer onafhanklik van die dosent en inoefening vind sinvoller in die praktyk plaas

Die dosent se rol is dus raad-, brongewer en fasiliteerder. Veranderlikes wat die vaardigheidsvlak van die student in " $n$ gesimuleerde omgewing kan belnvloed is:

- die groep grootte van die studente;

- die grootte van die lokaal waar simulasie plaasvind:

- die betrokkenheid van die studente;

- die gesimuleerde omgewing ' $n$ weerspexling van die werklike situasie en

- hoe die dosente simulasie as onderrigstrategic aanwend (Ross 1988 : 7 ; Lange 1972: 11 - 16)

Volgens die respondente $(100 \%)$ varieer die tydsverloop vanaf inoefening in simulasie en die kontaktyd in die werklike situasie (Kliniese praktyk). Die redes wat die respondente gegee het, was dat die studente op nagdiens geplaas word en die studente meld self an wanneer sy gereed is vir evaluering. Die tydsverloop het gevarieer van 1 tot 3 weke voordat die dosent die studente in die praktyk gekontak het. Die tydsverloop is te lank uit mekar, want die beklemtoning van leerervaring is effektief indien dit binne eenweek nadat dit in simulasie onderrig is in die kliniese praktyk opgevolg word. Die rede hiervoor is, dat die leergeleentheid wasraan die studente blootgestel was, vergeet word 
indien sy dit nie inoefen nie (Lange $1972: 21$ - 23; Beekman 1985 : 144 - 146)

Dit is egter nie moontlik vir die studente om al hul vaardighede onder begeleiding van die dosent in die kliniese praktyk in te oefen nie, want volgens die twee-en-dertig (100\%) respondente is die dosent nie deurentyd beskikbaar nie, omdat sy verskillende jaargroep studente hanteer en die studente werk ook nagdiens. Die studente moet ook van die cenheidsbestuurder in die kliniese praktyk gebruik maak. Tien $(31 \%)$ van die respondente maak van die cenheidsbestuurder gebruik om kriterium verwysigingskaarte te evalueer. Die rede waarom die studente die eenheidsbestuurder so min gebruik, is omdat sy te besig is volgens twee-en-dertig (100\%) van die respondente.

Evaluering van die studente se vaardigheidsvlakke vind plaas soos die geleentheid voorkom. Die dosent kan nie self al die vaardighede bepland by die student evalueer nie, as gevolg van die verskillende jaargroepe wat die dosent begelei en die student werk nagdiens. Die dosente en studente verkjes die volgende metodes van evaluering:

\section{TABEL 4.3 Metode van evaluering}

\begin{tabular}{lll}
$\begin{array}{l}\text { Motode } \\
\text { Geleentheids- } \\
\text { ovaluering }\end{array}$ & Dosente & Studente \\
$\begin{array}{l}\text { Vormend } \\
\text { Deurlopend }\end{array}$ & $32(100 \%)$ & $15(47 \%)$ \\
$\begin{array}{l}\text { Kiniese eksamen } \\
\text { aan die einde van } \\
\text { elke jaar }\end{array}$ & $32(100 \%)$ & $32(100 \%)$ \\
$\begin{array}{l}\text { Opvolg } \\
\text { begeleiding en } \\
\text { gestandardiseerde } \\
\text { kliniese evaluering } \\
\text { Kriterium } \\
\text { vermysingskaarte }\end{array}$ & $32(100 \%)$ & $32(100 \%)$ \\
Kontrolelys & $32(100 \%)$ & $32(100 \%)$ \\
\hline
\end{tabular}

Uit bogenoemde resultate verkies die dosent by Ann Latsky Verplegingskollege die huidige evalueringstelsel

\section{STRUKTUUR}

A. Student

Biografiese inligting

Die biografiese inligting het bestaan uit

- Hospitale waar studente kliniese praktika doen;

- Ouderdomsgroepe,

- Akademiese jaargroepe en

- Herhaling van ' $n$ studiejaar

Die aantal respondente volgens hospitale wat die struktuur vraelys voltooi het:
Hendrik van der $B_{i j l}=1$ student

Vereeniging $=4$ studente

Paardekraal $=5$ studente

Kemptonpark $=6$ studente

Willem Cruywagen $=7$ studente

J.G. Strijdom $=9$ studente

Die ouderdomsgroep verspreiding van die kandidate is as volg:

- 7 Studente kom voor in die ouderdomsgroep 18 - 19 jaar

- 15 Studente tussen die ouderdom 20 - 21 jaar

- 7 Studente tussen die ouderdom 22 - 23 jaar

- 2 Studente tussen die ouderdom $24-25$ jaar

- 1 Student tussen die ouderom 26 en ouer

Die respondente wat die struktuur vraelys voltooi het kom dus in dié last adollessente stadia voor.

\section{KONKRETE ERVARING}

Die studente, twee-en-twintig $(69 \%)$ doen hoofsaaklik hulle voorbereiding vir gerigte praktykleiding tuis.

Die fasiliteite wat beskikbar is ter voorbereiding vir gerigte praktykleiding is biblioteekboeke en 'n televisieskerm gekoppel aan ' $n$ video-opnamemasjien. Een-en-twintig (66\%) van die studente vind dat die dosente ten alle tye beskikbar is. Studente wat die eenheidsbestuurder nooit gebruik in voorbereiding vir gerigte praktykleiding was vyftien $(47 \%)$. Die motivering hiervoor is dat die eenheidsbestuurder te besig is wat ook bespreek is by die proses vraelys van die dosent. Die fasiliteite wat die studente vir gerigte praktykleiding en simulasie beskikbaar sou wou hê was

a) Televisieskerm en vidoo-opnamemasjien;

b) Biblioteekboeke;

c) Rekenaar programmatuur;

d) Klankskyfie projehtor en programmatuur;

e) Tydskrifte;

f) Lewensgetroue hospitaalsaal met realistiese voorrade en toerusting:

g) Modelle en

h) Videoprogrammatuur

Uit die fasiliteıte wat beskikbar is en dit wat die studente tol hulle beskikking sou wou he, dui daarop dat media onvoldoende voorsien is, in die kliniese departemente.

\section{REFLEKTIEWE WAARNEMING}

Die fasiliteite wat die studente ( $32-100 \%)$ benut, om meer te wete te kom oor 'n onderwerp of as noodsaaklik beskou vir verrykende aktiwiteite direk na kliniese onderrig in simulasie is:

a) Biblioteckboeke;

b) Groepbesprekingslokale;

c) Videoprogrammatuur en

d) Tydskrifte.

\section{AKTIEWE EKSPERIMENTERING}

Negentien ( $59 \%$ ) van die studente voel dat die fasiliteite vir onderrig in simulasie onvoldoende is. Sewe (36\%) voel dat daar ' $n$ mate van ooreenkoms met die hospital is. Studente, (vyftien (47\%) sou verkies dat lewensgetroue voorrade en toerusting gebruik word). Moer as die helfde van die studente $(59 \%)$ meld hulle het ten alle tye toegang tot 'n oefenlokaal om kliniese vaardighede in te oefen, sou wou hê. Volgens genoemde bevindings is die fasiliteite voorsiening in simulasie onvoldoende

\section{B. DOSENT}

\section{Biografiese inligting}

Die biografiese inligting het bestaan uit:

- Aantal dosente betrokke by kliniese begeleiding;

- Jaargroepe waarby dosente betrokke is;

- Teorie en praktyk uitruilbaarheid en

- Gemiddelde hoeveelheid studente per G.P.L. sessic

Agtien dosente (56\%) is uitruilbaar tussen teorie en praktyk. Die gemiddelde hoeveelheid studente per G.P.L. sessie wissel tusssen $6 \cdot 10$ studente.

Simulasie fasiliteit

Agt (25\%) van die dosente gebruik simulasie as onderrigstrategie

Toerusting in kliniese lokale bevat nie ' $n$ klankskyfieprojektor, video-opnamemasjien met televisie- skerm en truprojektor nie Hierdie inligting stem ooreen met die studente se interpretasie. Sewe $(22 \%)$ van die dosente meld dat die simulasie area ' $n$ mate van ooreenkoms toon met ' $n$ saal in die werklike siluasie.

Die dosente ervar dat die bestaande fasiliteite om vaardighede in simulasic te onderrig voldoende is. Vyf $(16 \%)$ van die dosente wat 
gemeld het dat die fasiliteite onvoldoende is, voer die volgende redes aan:

a) Pop en bed is onvoldoende;

b) Geen suurstof, suigingsfasiliteite nie;

e) Te veel persone maak van fasiliteite gebruik en

d) Modelle is beperk.

Redes wat aangevoer is waarom die fasiliteite nie altyd toeganklik is vir die studente is:

a) Te min toerusting en voorraad;

b) Mag slegs gebruik word wanneer dosente beskikbaar is;

c) Word beset deur ander groepstudente;

d) Die lokaal word om 16:00 gesluit. Die dosente weerspreek hulleself in die proses vraelys want vyftien (47\%) beskou hulself vaardig om simulasic as onderrigstrategie te gebruik teenoor die honderd persent in die struktuur vraelys. Die betroubaarheid van die inligting wat in die vraelys weergegee word, word betwyfel. Die redes waarom die dosente (17-53\%) hulself as bevoeg beskou was:

- Inoefening gedurende my eie praktika gee my genoeg selfvertroue om simulasie as onderrigstrategie effektief te gebruik;

- Met ervaring word leemtes oorbrug en

- Het voldoende praktiese ondervinding

Die dosente $(100 \%)$ beskou hul rol as fasiliteer, demonstreerder van vaardighede, verskaffer van inligting en evalueerder. Die vaardighede wat die dosente graag sou wou aanbied, maar nie oor die nodige fasiliteite beskik nie, is:

- Uitdeel van medikasie;

- Hantering van ' $n$ medisynetrollie;

- Kateterversorging van ' $n$ manlike pasiènt,

- Inhalasieterapie;

- Kardio-pulmonale ressusitasie;

- Passering van 'n maagbuis;

- Isolasieverpleging;

- Neem van vitale tekens en

- Neem van bloedglukose.

Hierdie inligting dui aan dat die simulasie lokale nie toegerus is vir die vaardighede wat die studente moet inoefen nie. Alhoewel hierdie fasiliteite ook in die kliniese praktyk benut kan word deur die dosent en studente.
GEVOLGTREKKING EN

AANBEVELINGS

Inleiding

Die navorsing het die volgende bepaal:

- Die bevoegdheid van die dosent met betrekking tot die gebruik van simulasie as onderrigstrategie en beskikbaarheid van onderrigfasiliteite.

- Die mate waarin die infrastruktuur hom tot simulasie verleen.

- Die student se verwagtinge ten opsigte van simulasie as onderrigstrategie tydens kliniese begeleiding.

\section{A. PROSES (Student en dosent)}

\section{Voorbereiding en voorvereiste kennis}

Die studente wat die voorvereiste kennis moet bereik spandeer nie tyd daaraan nie of spandeer meer as 3 ure aan die bereiking van doelwitte (verwys na paragraaf 1.2). Die navorsers stel voor dat doelwitte tydens die blokprogram gedurende kollege tyd bereik moet word, sodat die student geleentheid het om dit in die praktyk te internaliseer. Drie-en-vyftig persent van die dosente evalueer voorvereiste kennis volgens hul eie metodes of benadering, vir 'n onervare dosent wat die verpleegonderwys beroep toetree, benodig sy struktuur om voorvereiste kennis te toets (verwys na paragraaf 1.2 en 1.3 ). Om eenvormige evaluering te verseker moet die dosent tydens orientasie, georienteer word met betrekking tot die strategiee waarvolgens voorvereiste kennis getoets behoort te word Indien die studente nie voorbereid is vir ' $n$ gerigte praktykleidingsessie, moet sy weet wat is die korrekte hantering daarvan en al die dosente moet dieselfde bensdering volg om verwarring by studente uit te skakel.

\section{Konkrete ervaring}

In die verslag oor die meningsopname onder vierdejaar studente van 1989 het die helfte van die studente simulasie van waarde geag. Uit die navorsingsprojek kon (75\%) van die studente die betekenis van simulasie verduidelik. Die navorsingsresultate dui aan dat die studente weet wat beteken simulasie en dit as effektief ervaar vir die inoefening van vaardighede (verwys na paragraaf 1.4).

Die rede warom slegs $47 \%$ van die dosente van simulasie as onderrigstrategie gebruik mak is, dat onderrigstrategiee soos demonstrasies, gevallestudies, rolspel, saalrondies en 'n kombinasie van strategiee gebruik word. Dertig ( $94 \%$ ) van die studente meld dat praktiese vaardighede in simulasic aangeleer word. Vyftien (47\%) van die dosente mak gebruik van simulasie wanneer die geleentheid kom voordoen.

Met die beantwoording van die proses en struktuur vraelys deur die dosente het die antwoorde verskillende reaksies uitgelok. Uit die proses vraelys het die dosente gemeld dat vyftien (47\%) hulself varardig beskou om simulasie te gebruik. In die struktuur vraelys het twee-en-dertig (100\%) bevoeg gevoel om simulasie as onderrigstrategie te implementeer. Die dosente weerspreek hulself en dit kan die betroubaarheid van die inligting verkry uit die vraelyste beinvloed.

Die navorsers stel voor dat alle personeel ' $n$ personeelontwikkelingsprogram moet bywoon om onderrigstrategice op te knap asook hoe om simulasie efektief te implementeer. Die dosente wat somtyds nie voorbereid was vir gerigte praktykleiding nie kon ook die indruk skep dat simulasie nie effektief plaasvind nie en weens die verskillende jaargroepe wat hulle hanteer nié die geleentheid het vir voorbereiding nie. Die dosent moet deeglik voorbereid wees ten opsigte van die rexls van 'n gegewe simulasiestrategie, asook die spesifieke riglyne wat aan studente gegee behoort te word om effektiewe leer tot gevolg te hê (De Villiers 1975 : 47).

Simulasie word nie net gebruik vir die aanleer van vaardighede nie, maak ook vir evaluering en hersiening. Nege-en-twintig (91\%) van die studente neem self deel aan aktiwiteite in simulasie en dit dui op die aktiewe betrokkenheid van die studente in haar eie onderrigsituasic. Twee-en-dertig (100\%) van die dosente beskou simulasie as ' $n$ waardevolle strategie en betrek die studente deur middel van vraagstelling, bespreking en demonstrasies.

Twee-en-dertig (100\%) van die dosente het gemeld dat vardighede so na as moontlik aan die werklikheid uitgevoer word. Die student beleef dit nie so nie omdat die simulasie area nie die werklikheid weerspickl nie. Dit kan toegeskryf word aan die beperkte toerusting en dat die area elke keer weer opgestel moet word en nog steeds nie soos 'n saal realiseer nie.

\section{Reflektiewe waarneming}

Nege-en-twintig $(91 \%)$ van die studente beweer dat leer wat in simulasie plaasvind opgevolg word. Iwee-en-dertig (100\%) van die dosente volg vaardighede wat in simulasie uitgevoer word op, deur middel van verskillende strategiee te gebruik. byvoorbeeld groepbesprekings, inoefening en evaluering tydens inoefening.

Die kollegebeleid maak njé volgens sestien $(50 \%)$ van die dosente voorsiening vir simulasie nie. Die bestaande kollege onderrigbeleid is uitvoerbaar en word deur agtien $(56 \%)$ van die dosente so ervaar Hieruit kan afgelei word dat die dosente onseker is oor die inhoud van die onderrigbeleid

Omdat die student vaardighede eers in simulasic inoefen, ontwikkel die student selfvertroue en vaardigheid om kliniese praktyk aktiwiteite in die werklike situasie uit 
te voer en voorkom sodoende regsgeneeskundige risiko's. Die bestaande kollegebeleid moet hersien word sodat vir simulasie as onderrigstrategie voorsiening maak.

\section{Abstrakte konseptualisering}

Uit die vraelyste kom dit voor asof die studente, een-en-dertig (97\%) aangemoedig word om konsepte te formuleer. Teenoor die dosente dertien (4l\%) wat nie seker was oor die gebruik van konsepformulering nie Hierdie bevinding belnvloed ook die betroubas rheid van die inligting verkry uit die vraelyste.

Volgens die navorsers behoort die dosente volgens die jaargroep waar hulle funksioneer personeelontwikkeling te ontvang met betrekking tot teorie- en praktykintegrasie.

\section{Eksperimentering}

Een-en-dertig $(97 \%)$ van die studentverpleegkundiges ervaar simulasie as ' $n$ onderrigstrategie wat effektiewe werksverrigting in die werklike situasie bevorder.

Die dosente benut simulasie volgens die situasie soos wat dit voorkom. Die positiewe ervaring wat studentverver- pleegkundiges met simulasie gehad het, beklemtoon dus die optimale benutting van simulasie as onderrigstrategie.

\section{B. STRUKTUUR (Dosent en student)}

\section{Konkrete ervaring}

Die fasiliteite wat die studentverpleegkundiges in gerigte praktyk leiding gebruik is boeke, video- programmatuur en televisieskerms. Die dosente het 'n ideale dosent tot student ratio per sessie, $6-10$ (studente) en dit kan die gebruik van simulasie as onderrigstrategie se effektiwiteit bevorder.

Vyf-en-twintig (78\%) van die studente beweer dat ' $n$ lewensgetroue hospitaalsaal met realistiese voorrade en toerusting van waarde is. Nie een van die kliniese departemente beskik oor of die fasiliteite om ' $n$ effektiewe gesimuleerde omgewing daar te stel nie. Uit die navorsingsresultate is bevind dat ' $n$ simulasie laboratorium onontbeerlik is in die kliniese praktyk. Die aanbeveling vir een volledig toegeruste simulasic laboratorium wat deurgaans toeganklik is vir die studente word gemaak

Reflektiewe wasneming en aktiewe eksperimentering

Die fasiliteite wat die studente benut na afloop van kliniese onderrig in simulasie is, biblioleekboeke, groepsbesprekingsmodelle, lokale, tydskriffe en videoprogrammatuur Die beskrywing wat die dosente gegee het oor die lokale wat vir simul asie gebruik word, was dat daar ' $n$ mate van ooreenkoms is met' $n$ saal in die hospitaal. Veertien $(\mathbf{7 4 \%})$ van die dosente meld dat die fasiliteite ten alle tye toeganklik is vir die studente vir die inoefening van vaardighede teenoor die studente $(59 \%)$ wat meld dat hulle ten alle tye toegang tot die fasiliteite sou wou hê

Die sienswyse van die studente en dosente verskil dus oor die toeganklikheid van die fasiliteite. Die navorsers stel voor dal die toeganklikheid van die simulasiefasiliteite in die onderrigbeleid vervat moet word en dat die studente onbeperk toegang het.

\section{SLOT}

In hierdie ondersock is die benutting van simulasie as onderrigstrategie in kliniese onderrig ter sprake. Die navorsers wil die vertroue uitspreek dat die studie sal bydra tot die optimale benutting van simulasie in verpleegonderwys. Indien die aanbevelings toegepas word sal die studie aanleiding $g \propto e$ tot 'n verpleegpraktyk waar die studentverpleegkundige vasidighede sinvol en suksesvol benut binne die konteks van wetenstiplike verpleging

\section{VERWYSINGS}

Allan, P. \& Jolley, M. (1987). THE CURRICULUM IN NURSNG EDUCATION. London: Croom Helm.

Brink, H.I.L. (1992). Writing a Research Proposal NURSING RSA, 7,2, 34-37.

Beekman, A.W. (1990). Simulasie in Perspektief VERPLEGING RSA, 5,4, 31-33.

Beekman, A.W. (1985). SIMULASIE AS ONDERRIGMODALITEIT IN VERPLEEGONDERWYS. Porchefstroom: Die Universiteit van Potchefstroom

Bevis, E.O. (1932). CURRICULUM BUILDING IN NURSING. A PROCESS. 3rd edition. St Louis : Mosby.

Bester, M.J.E. (1990). KENNIS EN VERWAGTINGE VAN DIE PRIMAGRAVIDA OOR BARING. Johannesburg : RAU.

De VIlllers, F.M.J. (1975). DIDAKTIESE ONTWERP VIR KLINIESE ONDERRIG IN VERPLEGING. Pretoria : SAVV

Dejon, W.L. (1978). PRINCIPLES OF MANAGEMENT. London: Benjamin /Cummings.

Ewan, C. \& White, R. (1989). TEACHING NURSING A SELF INSTRUCTIONNAL HANDBOOK London : Croom Helm.

Gooven, H. (1989). WHERE PATIENTS NEVER COMPLAIN SOUTH AFRICA PANORAMA, 44-47.

Gartalde, G. \& Me Gough, S. (1991). High Profiles NURSING TTMES, 87,4, 40-41.

Gullbert, J.J. (1987). EDUCATIONAL HANDBOOK FOR HEALTH PERSONELL Revised edition Geneva : W.H.O.

Guinec, K.K. (1966). THE AIMS AND METHODS OF NURSING EDUCATION New York: Mac Millan.

Hozemer, W.L (1980) THE STRUCTURE OF PROBLEM SOLVING IN SIMULATIONS NURSING RESEARCH. 35,4, 231-235.
Holbert C.M. \& Thomas K.J. (1983). Towerd Whole Brain Education NURSE EDUCATOR. $13,1,30-34$.

Knomles, MS. (1980), ADULT LEARNING. A NEGLECTED SPECIES. Houston : Gulf.

KIdd, J.R. (1973). HOW ADULTS LEARN. Chicago : Association Press.

King. E.C. (1992), AFFECTIVE EDUCATION IN NURSING. A GUIDE TO TEACHING AND ASSESSMENT. U.S.A.: Aspen

Lange, C.M. (1972). AUTOTUTORIAL TECHNIOUES IN NURSING EDUCATION. NEW JERSEY : ENGLEWOOD CLIFFS.

Mager, R.F. (1980). DIE VOORBEREIDINC VAN ONDERRIGDOELWITTE. Fearon Nasou

MeGnire, C.H. \& Wezeman, H. (1974). WRITTEN SIMULATION THEIR CONSTRUCTION AND ANALYSIS. Chicago : University of Illinois College of Medicine.

Mellish, J.M. (1982). TEACHING THE PRACTICE OF NURSING. Durban Butierworths.

Mellish, J.M (1987), UNIT TEACHING AND ADMINIS TRATION. Durben: Bumerworths.

Muller, M. (1989). Die skep van Optimale leeromgewing VERPLEGNG RSA, 4,2, 21-25.

Nolte, A.G.W. (1986). Simulasie as Kliniese onderrigmetode in Verloskunde. VERPLEGING RSA, 1,11, 12-13, 28.

Nieben, B.B. (1990). Applying Andragogy in Nursing Comtinuing Education. JOURNAL OF CONTINUING NURSING EDUCATION, 20,2,86-90

Nel, A.H. \& Bason, A.A. (1988). Spesifieke Leergeleenthede in Gesondheidsopvoeding. VERPLEGNG RSA, 11,3, 23-27.

Odendal, F.F. Swanepoeh, C.J., Du Tolt, C.J., Boovien, C.M. \& Schoomen, P.C. (1979). HAT VERKLARENDE WOORDEBOEK VAN DIE AFRIKAANSE TAAL Johannesburg : Penkor.

Pollt, D.F. \& Hungler, B.P. (1937), NURSING RESEARCH. PRINCIPLES AND METHODS. (3rd edition) Philadelphia: J.B. Lippincott.

Pohl M.L (1982), THE TEACHING FUNCTION OF THE NURSE PRACTITIONER. (4th edition). lowa : W.M.C. Brown.

Pendleton. S. Myles, A. (1991), CURRICULUM PLANNING IN NURSING EDUCATION. London : Croom Helm.

Quinn, F.M. (1988) THE PRINCIPLES AND PRACTICE OF NURSING EDUCATION. London : Croom Helm.

Reybould, E (1975). A GUIDE FOR TEACHERS OF NURSES. London: Bleckwell.

Reilly, D.E aerman, M.H. (1985). THE CLINICAL FIELD : ITS USE IN NURSING EDUCATION. Norwalk / Connecticut Appleton- Century-Croft.

Roan N. (1988). The use of an Extended Simulation in Ward Management. Training Rationate for Development and Design Crileria. NURSE EDUCATION TODAY, 8, 48 .

Swart, J. (1992), Can Simulation Replace Practica? NURSING RSA. 7,4, 35-38.

Shether, A. (1989). Completed Certified C.P.R. AMERICAN JOURNAL OF NURSING, 89,4, 348. 
Suld-Afrke (1978) WET TOT SAMEVATTING EN WYSIONNG VAN DIE WETBEPALING MET BETREKKING TOT DIE BEROEPE VAN GEREGISTREERDE OF INGESKREWE VERPLEEGKUNDIGES VERPLEEGASSISTENTE EN VROEDVROU EN OM VIR BYKOMSTIGE AANGELEENTHEDE VOORSIENING TE MAAK. Pretoria: Stantsdrukkers. (Wet no. 50 van 1978 : Wet op Verpleging 1978 (soos gewysig).

Die Suld-Afnlcane Rend op verpleding. (1988) BELEID EN GEMEENSKAPLIKE KURRIKULUM A Gewyig Mart (1988)

Suld-Afrika. (1985). REGULASIES BETREFFENDE DIE GOEDKEURING VAN EN MINIMUM VEREISTES VIR DIE OPLEIDING EN ONDERRIG VAN ' $N$ VER PLEEGKUNDIGE (ALGEMENEPSIGIATRIESE-, GEMEENSKAPS-) EN VROEDVROU WAT LEI TOT REGISTRASIE R425 (s00s gewysig)

Tobin, H.M. \& Yoder, P.S \& Hull, P.K. \& Scoth, B.C. (1974). THE PROCESS OF STAFF DEVELOPMENT. Saint Louis: Mosby.

Treece, EW. \& Treece, J.W. (1986), ELEMENTS OF RESEARCH D NURSING. (4th odition) Toronto : Mosby,

Tansey, PJ. (1971). EDUCATIONAL ASPECTS OF SIMULATION. London: Mc Graw-Hill.

Univeratteit van Suld-Afrike, DEPARTEMENT VERPLEEGKUNDE. (1990) VERPLEEGONDERWYS: Studiegids vir NUE 203-D Hersiene uitgawe. Pretoria.

Uys, H.M.M. (1991). Die Outotutoriale Onderrigmodel as Metode tot die Individualisering van Onderrig an die R.A.U. INTERNE PUBLIKASIE, Buro vir Universiteitsonderwys, 20,86, 18.

Uys, H.H.M. A Basson, A.A. (1983). NAVORSINGSMETODOLOGIE IN DIE VERPLEEGKUNDE. Pretoria: HAUM.

Van der Stoep, F. (1969). DIDAKTIESE GRONDVORME. Pretoria: Academica.

Vermeulen, J. (1990). VERSLAG OOR DIE MENINGSOPNAME ONDER DIE 4DE JAAR STUDENTE VAN (1989), OM HULLE HOUDING TEENOOR DIE BASIESE OPLEIDINGSPROGRAM TE BEPAAL. Pretoria: Transvaalse Provinsiale Administrasie. 13.

\begin{tabular}{|c|} 
JS Crous D.CUR \\
Senior Dosent \\
ANN LATSKY \\
VERPLEGINGSKOLLEGE \\
L de Villiers M.CUR \\
Senior Dosent \\
ANN LATSKY \\
VERPLEGINGSKOLLEGE \\
C MOUton \\
Senior DoSent \\
ANN LATSKY \\
VERPLEGINGSKOLLEGE \\
T BOyerS \\
SEnior Dosent \\
ANN LATSKY \\
VERPLEGINGSKOLLEGE
\end{tabular}

BOOK REVIEW

\section{PROFESSIONAL PRACTICE}

\author{
C SEARLE and SA PERA \\ Published Butterworths Third Edition 1995. \\ ISBN 0409109304 - Price R114.00 (inc. VAT)
}

The inclusion of the historical development of professional practice in the countries of the Southern African Region, giving a Southern African perspective, is an important and timeous addition to this well established textbook. In the present-day spirit of mutual co-operation in the development of the region it is important to rocognise the commonality of professional concerns; progress towards legal regulation has roots in the similar pasts of these countries and it is useful to clearly understand and appreciate the common needs and aspirations which are greater than the differences.

In the development of legal regulation and ethical practice, the South African Nursing Council played a central rôle in all the countries of the Southern African Region, and as South Africa once again emerges to take her rightful place internationally and as a leader in the region, it is essential that nurses of this country are ready and able to continue to make valuable contributions to the evolution of nursing practice and regulation as in the past, nationally, internationally and regionally. The authors point out in this Third Edition that the evolutionary process of the principle of professional practice "imposes an obligation on the professions to study constantly that which lies at the roots of quality nursing and midwifery and fulfilment of nursing and midwifery's contract with society at large."

As in previous oditions of this important work, the legal parameters and implications of professional practice are clearly and succinctly set out leaving no room for doubt, misunderstanding or misinterpretation.

As this country moves through the present transitional phase in our history where the foundations of existing legal structures at the highest level of constitution-making are being questioned, analyzed, and re-written (incorporating and at times re-defming such concepts as human rights) every institution is affected to some degree. This includes all professional institutions and structures, and from the point of view of the nursing profession it is the duty and obligation of every nurse to know and fully understand the legalities involved in professional practice and the ethical foundations which underpin them. It is only this depth of knowledge which will enable the profession to honestly fact the challenges of today and the future.

Ethical issues which arise from advances in medical technology, freedom of thought and action, and the emergency of women's rights movements throughout the world often place the professional nurse practitioner in ethical dilemmas where there appear to be no clear cut solutions. Such issues are dealt within the book providing both challenges to individual thinking and legal pointers and concepts for analysis.

This updated edition of Professional Practice is a must on the bookshelves of all levels of nursing students, and all professional nurses who are seriously involved in their profession and it's future.
Philippa Burton

(Rotired) Chief Nursing Otficer

Municipal Department of Health DURBAN 